\title{
EFFICACY ASSESSMENT OF THE SCHEME FOR PREVENTION OF HERPESVIRUS INFECTION MANIFESTATIONS IN THE ORAL CAVITY OF PATIENTS WITH HERPES-ASSOCIATED GENERALIZED MODERATE SEVERITY PERIODONTITIS
}

DOI: 10.36740/WLek202003134

\author{
Tetiana M. Volosovets, Anna V. Kravchenko \\ SHUPYK NATIONAL MEDICAL ACADEMY OF POSTGRADUATE EDUCATION, KYIV, UKRAINE
}

\begin{abstract}
The aim: Efficacy assessment of herpesvirus infection drug prophylaxis (HVI) manifestations in the mouth of patients with chronic herpes-associated generalized periodontitis (CHGP) of moderate severity during and shortly after closed curettage.

Materials and methods: The total of 87 patients with CHGP of moderate severity aged 35-60 years were examined and divided into groups according to the presence of HVl: Group I (main) included 48 patients who had herpesvirus infection; group II (comparison) - 39 patients who were not found herpesvirus infection. Group III was formed based on the data of out-patient medical reports retrospective analysis and was used to compare the number of complication cases. The control group included 20 patients with intact periodontium.

Prior to treatment, patients in group I, was additionally assigned multicomponent phytocomplex. The treatment efficacy was assessed by the concentration dynamics of A,, , M immunoglobulins, circulating immune complexes (CIC) and slgA, hygienic and periodontal indices, as well as by the dynamics of gum fluid and the recovery terms.

Results: The study on the dynamics of clinical indices and some humoral immunity indices confirmed the main group patients after closed curettage had positive shifts in slgA, IgA, IgG, IgM and CIC levels. Their indices did not have a statistically significant difference with similar indicators of the comparison group. In group I, complications in the form of HVI manifestations in the buccal mucous membrane (BMM) were found in $8.33 \%$ of patients, which had a statistically significant difference $(p<0.001)$ from the percentage of patients with HVI, with complications in group III (35.71\%). The recovery terms for patients in group I were by $16.7 \%$ shorter than the similar terms in group III. Conclusions: The results obtained indicate that the phytocomplex used by us can be applied as an immunomodulatory agent for the prevention of herpes virus infection manifestations in the oral cavity of patients with interventions in BMM and periodontal tissues.
\end{abstract}

KEY WORDS: generalized periodontitis, curettage, herpes virus infection

\section{INTRODUCTION}

According to the WHO, 70 to $90 \%$ of the world's population is infected with one or more herpes virus types and 50\% of them have a recurrence of the disease every year due to the lack of persistent immunity.

According to Slots et al. (2002) representatives of Herpesviridae viruses ( 1 and 2 types herpes and cytomegalovirus) constitute the microflora of the periodontal pocket in patients over 45 years of age with chronic generalized periodontitis. In $80 \%$ of patients with chronic generalized periodontitis, signs of secondary immune deficiency are observed in the exacerbation phase against the background of recurrent herpes virus infection.

A number of researchers have confirmed the role of immune mechanisms in the pathogenesis of inflammatory periodontal diseases caused by viral-bacterial association $[1,2,3]$. The interaction between herpes virus and bacterial flora is likely to have a bidirectional correlation, taking into account the activity of bacterial enzymes and other factors that induce inflammation and cause involvement of herpes virus in the pathology development. Herpes viruses can cause periodontal tissue disease directly - both as a result of the virus infection and its replication in the body, and as a result of the indirect impact of virions on the body's protection system.

Patients affected by chronic herpes virus infection not only have a more severe periodontal disease course but also a deeper nature of the immune system changes compared to patients who have similar periodontal tissue pathology but are not HVI-carriers, as evidenced by the analysis of numerical studies on the cell and humoral components of the immune system $[4,5]$.

For the comprehensive treatment of herpes virus infection, nucleoside analogues are used, as a rule, as antiviral chemotherapy drugs. They block the herpesviruses replication by suppression of viral DNA polymerase and inhibiting DNA synthesis. However, these drugs only act on the virus at the stage of active replication, have low bioavailability and a number of toxic effects. Today, an increasing number of viral strains resistant to the action of these drugs are recorded $[6,7,8]$. 
The reason to refuse drugs for external use only in treatment of herpes virus infection was the increasing incidence of herpes infection overt symptoms exacerbations, which is now widely recognized and documented in international recommendations. The efficacy of treating chronic generalized periodontitis associated with persistent herpes virus infection depends not only on the specific antiviral drugs used in the case of herpes virus infection in the virus carriers' oral cavity, but also on the immunocorrection therapy. Therefore, the problem of developing and applying the existing prevention regimens for these conditions remains relevant.

\section{THE AIM}

The purpose of this study was to assess the efficacy of the scheme developed by the authors for the drug prevention of herpes virus infection manifestations in the oral cavity of patients with chronic generalized periodontitis of moderate severity during surgical treatment (closed curettage) and in the short term after it.

\section{MATERIALS AND METHODS}

Materials and methods of the study. The study is carried out in compliance with the main provisions of the GCP ICH and the Helsinki Declaration on Ethical Principles for Medical Research Involving Human Subjects, and its subsequent revisions (Seoul, 2008), the Council of Europe Convention on Human Rights and Biomedicine (2007) and the recommendations of the Committee on Bioethics at Presidium of the NAMS of Ukraine (2002) and the positive opinion of the Shupyk NMAPE Committee on Ethics (excerpt from Minutes No. 2 of 10/01/2017).

To fulfil these tasks, 87 patients with chronic generalized periodontitis (CGP) of moderate severity aged 35 to 60 years were examined.

Within the framework of the study, for the purpose of comparative analysis, we also performed a retrospective analysis of 28 out-patient medical records of patients who were herpes virus carriers and were treated for moderate-severity CGP with the use of closed curettage by the traditional method [9].

The control group consisted of 20 patients who had no periodontal tissue disease and consulted a dentist for treatment of uncomplicated caries.

Verification of the "generalized periodontitis" diagnosis was carried out based on conventional clinical and paraclinical examination methods with determining of periodontal PI index III (by Russel), PMA (by Parma), gum recession assessment (by P.D. Miller). Oral hygiene status was assessed using the Green - Vermillion index. The diagnosis was confirmed by radiography.

Patients whose depth of periodontal pockets did not exceed $4 \mathrm{~mm}$ were involved into the study. Before treatment, patients were asked to complete a questionnaire, which included questions about the presence of somatic diseases, bad habits (smoking), and the presence or absence of herpes virus manifestations in the patient during the last ten years of life.

According to the previous history it was established that 48 patients had manifested symptoms of herpes virus infection during their lifetime. Verification of the persistent herpes virus infection (HVI) diagnosis was performed based on anamnesis assessment, clinical course of the disease, differential diagnosis with similar diseases, enzyme immunoassay (EIA) and polymerase chain reaction (PCR).

Depending on the presence or absence of herpesvirus infection, patients were divided into two groups: Group I (main) included 48 patients who had herpesvirus infection; group II (comparison) - 39 patients who were not found herpesvirus infection. Group III was formed based on the data of out-patient medical reports retrospective analysis and was used to compare the number of complication cases in the form of herpes virus manifestations in the oral cavity during the closed curettage and the recovery terms after the use of traditional therapy methods without immunomodulating and antiviral drugs. The homogeneity of the patient groups was assessed in terms of their comparability on demographic and clinical grounds and was determined for the correctness of the treatment efficacy comparative analysis.

The immune protection status of patients in the both groups was determined by studying the concentration of A, G, M immunoglobulins, circulating immune complexes (CIC) in peripheral blood and sIgA in the oral fluid. The treatment efficacy was assessed by the dynamics of hygienic and periodontal indices, as well as by the gum fluid dynamics indices and by the recovery terms.

\section{RESULTS}

Objective examination of the oral cavity in groups I and II patients revealed the presence of soft dental deposits and mineralized supra- and subgingival dental deposits. The hygiene index in the main group was worse $(22.1 \%)$ than that in the comparison group and had a statistically significant difference with the similar index in the control group. The clinical picture was characterized by gums hyperemia with pronounced cyanosis, pronounced edema, disturbed turgor of gum tissue and the gingival margin relief, gum pain and bleeding, traumatic occlusion. More intense gum inflammation and more pronounced clinical tissue changes of the periodontal complex were determined in group I patients.

The periodontal indices values in the patients belonging to this group significantly exceeded the values of similar indices in the comparison group patients: PMA - by $28.29 \%$ ( $\mathrm{p}<0.001)$; RVI - by $12.14 \%$ ( $\mathrm{p}<0.001$ ); RI - by $23.9 \%$ $(\mathrm{p}<0.001)$. The mean depth of periodontal pockets in patients of group I was $3.72 \pm 0.34 \mathrm{~mm}$, whereas in patients of group II they were $3.28 \pm 0.31 \mathrm{~mm}$. The amount of gum fluid in the gingival crevice and in the periodontal pocket of group I patients also exceeded the similar index in group II by 1.57 times $(\mathrm{p}<0.001)$, which indicated a greater severity 
of the inflammatory process in the periodontal margin of individuals with CGP associated with persistent herpes virus infection.

The study found that A ( $\operatorname{Ig} A)$ immunoglobulin values in group I patients exceeded those in the control patients by 1.35 times and in group II patients - by 1.06 times $(\mathrm{p}<0.05)$. G ( $\operatorname{IgG})$ immunoglobulin values also exceeded those in the control group by 2.08 and in group II - by 1.7 times ( $\mathrm{p}<0.001)$, respectively. M (IgM) immunoglobulin scores were also by 2.23 times higher than in the control group and by 1.7 times higher $(\mathrm{p}<0.001)$ than in group II. The values of circulating immune complexes (CIC) in group I patients also exceeded the similar indices in the control group patients by 4.14 and by 3.28 times $(\mathrm{p}<0.001)$ in group II, respectively.

Values of sIgA indices in the oral fluid also differed in group I $(0.081 \pm 0.006)$ and group II $(0.097 \pm 0.007)$ and had a statistically significant difference with those of the control group $(0.174 \pm 0.02)(\mathrm{p}<0.001)$.

The above studies suggest that an increase in IgA, IgG, IgM levels and a decrease in sIgA levels in patients of groups I and II are due to the presence of the bacterial infection as a pathogenic link in the development of inflammatory periodontal tissue diseases. In addition, in group I (main), this index was also influenced by persistent herpes virus infection, which also causes an increase in the serum immunoglobulin level and a decrease in sIgA titer in the oral fluid. The high CIC concentration in group I patients is explained by the fact that prolonged persistence of bacterial and viral infection in the body is accompanied by the immune system activation with formation of CIC, which subsequently re-trigger activation of cellular and humoral components of the immune system and, as a consequence, autoimmune response development.

All patients in phase I of generalized periodontitis treatment received standard local therapy, which included removal of supra- and sub-gingival calculus, correction of butts and elimination of other traumatic factors. After the inflammatory process subsidance, carious cavities were sanitated, traumatic occlusion items were removed [10 11]. Drug treatment included oral irrigation with antiseptic solutions, antibacterial therapy for periodontal pockets, anti-inflammatory and reparative treatment.

Prior to treatment, patients in group I, who were diagnosed with herpes virus infection, was additionally assigned multicomponent phytocomplex "Dzherelo-I" containing water-alcohol standardized extracts of aloe, plantain, sage, nettle, knotgrass, yarrow, echinacea, hypericum, organy, absinthium, sandy everlasting, thyme, bur beggar-ticks, calendula flowers, berries of viburnum, buckthorn, fruits of sweet-brier, fennel, juniper, roots of blowball, rhodiola, licorice, sweet calamus rhizome, rhizomes and roots of elecampane, tormentil rootstock, chaga (phytoextract). The purpose of the phytoextract prescription was to prevent the onset of herpes virus pathology manifestations in the oral cavity of patients at the stages of moderate severity CGP treatment. The drug has antimicrobial, antiviral, anti-inflammatory effect, sig- nificantly enhances the reparative function of immunity. Moreover the more pronounced immunosuppression is the stronger is the potentiating effect of the drug. The drug has good compatibility, it can be used not only on its own, but also with other drugs in the comprehensive treatment of most diseases. When applied to the skin and mucous membranes, the drug quickly reduces inflammation. The drug was prescribed for a comprehensive course of 21 days: for internal administration - 50-70 drops per 100 $\mathrm{ml}$ of water 2 times a day 40 minutes before meals; and for rinsing the oral cavity - in the ratio of 20-30 drops per 1 tablespoon of water. To consolidate the treatment effect, patients underwent closed curettage of periodontal pockets. At the time of surgery, patients in both I and II groups had an equivalent clinical picture of the disease course.

In order to prevent the development of systemic septicemia and to avoid bacterial endocarditis, patients were prescribed prophylactic oral administration of clindamycin: $600 \mathrm{mg}$ for 60 minutes [11]. The operation of closed curettage for both groups was performed in the area of four incisors in the mandible according to the conventional method and using local anesthesia with a solution of articaine hydrochloride and irrigation with a warm solution of antiseptic ( $0.05 \%$ solution of chlorhexidine bigluconate).

Patients of group I (main) and group II (comparison) received postoperative drug therapy according to the schemes, suggested and developed by us, which included oral administration of the serratiopeptidase drug.

The treatment regimen included: washing the periodontal pocket with a warm antiseptic solution $(0.05 \%$ solution of chlorhexidine bigluconate); instillation of the dental treatment paste into periodontal pockets in the surgery intervention site (mefenamic acid, vinylin - 2.0; zinc oxide - 2.0), which was prepared immediately before use; applying adhesive bandage (Reso-pac); assignment of serratiopeptidase for oral administration at the dose of $10 \mathrm{mg}$ three times a day 40 minutes before meals for 8 days. Patients of group I were additionally assigned " $\mathrm{Dz}$ herelo-I" phytocomplex solution to rinse mouth and for gingival applications in the proportion of $20-30$ drops for each tablespoon of warm water (solution prepared immediately before use and not stored) three times a day for three weeks. The control examination of patients was carried out on the second day after the surgery. The term of the second stage of surgery depends on the complaints and the clinical picture in the operation site.

At the second stage of surgery, the proposed regimens were supplemented with vitamin preparations (retinol acetate $3.44 \%$, tocopherol acetate $10 \%$ ) and reparative drugs (dental gel containing deproteinized hemoderivate of the calves blood). Patients of group I were additionally prescribed applications of the "Dzherelo-I" phytocomplex solution for 30 minutes 2 times a day to the diseased site. Patients were given recommendations on the features of nutrition and oral hygiene.

After the first stage of closed curettage, accompanied by the appropriate medical treatment, in group I, complications in the form of herpesvirus infection manifestations 
on the oral cavity mucous membrane, inflammatory and exudative phenomena were revealed in 4 patients (8.33\%) with moderate and severe herpesvirus infection course, which had a statistically significant difference $(\mathrm{p}<0.001)$ with the percentage of HVI-patients with acute complications in group III (10 patients amounting $35.71 \%$ ).

In addition, these patients complained of pain in the intervention site. For these patients, the second stage of closed curettage was delayed until the lesions epithelialization and was performed $6 \pm 2.18$ days after the first stage. To treat manifestations of herpes virus infection, this patient was prescribed inosine pranobex $500 \mathrm{mg}$ at the dose of 2 tablets 4 times a day for 14 days. No complications were found in patients of group II.

Patients of groups I and II who had no complications after the first stage of closed curettage, were performed the next stage three days after.

After the second stage of closed curettage, inflammatory exudation and pain in the intervention site disappeared on the 2nd-3rd day. As a rule, on the third day the signs of a pronounced inflammatory process subsided. Postoperative wound healing occurred within $5 \pm 1.26$ days after the manipulation in patients of group I and after $4.3 \pm 1.16$ days in patients of group II, as evidenced by the normalization of clinical indices presented in table 1 . When comparing the recovery terms in patients of groups I and III a statistically significant difference was found in the recovery terms. It was $5 \pm 1.26$ days in Group I versus $6 \pm 2.18$ days in Group III.

The assessment of the nearest clinical results in treatment of moderate severity CGP according to the suggested regimens in patients of groups I and II was carried out within 7 days after the second stage of closed curettage. Along with clinical indices, changes in the immune protection status in both groups were assessed. The values of sIgA, IgA, IgG, IgM and CIC levels in both groups I and II also had positive dynamics. Thus, as a result of treatment performed in group I, the level of sIgA increased significantly by $39.55 \%$.

The level of IgA decreased by $12.23 \%$; IgG - by $40.52 \%$; IgM - by $42.14 \%$. In group II, on the 7 th day after the second stage of closed curettage, the levels of immunoglobulins decreased: IgA - by $16.93 \%$; IgG - by $40.29 \%$; IgM - by $18.58 \%$. The level of sIgA increased by $38.22 \%$. The CIC level indices also had positive dynamics in both group I and group II. In group I, the reduction of the CIC level was 61.15\%; in group II - 59.71\%. Dynamics of the humoral immunity indices of patients in groups I and II

Table I. Dynamics of clinical indices in patients of groups I and II before and in the nearest terms after treatment

\begin{tabular}{|c|c|c|c|c|c|}
\hline \multirow[b]{2}{*}{ Indices } & \multirow{2}{*}{$\begin{array}{l}\text { Control group } \\
\qquad(n=20)\end{array}$} & \multicolumn{2}{|c|}{ Group I (n=48) } & \multicolumn{2}{|c|}{ Group II (n=39) } \\
\hline & & Before treatment & $\begin{array}{c}\text { After } \\
\text { treatment }\end{array}$ & Before treatment & $\begin{array}{c}\text { After } \\
\text { treatment }\end{array}$ \\
\hline IG & $0.32 \pm 0.08$ & $3.44 \pm 0.44$ & $0.93 \pm 0.04^{* * *}$ & $2.68 \pm 0.09$ & $0.36 \pm 0.08^{* * * *}$ \\
\hline PI & $0.1 \pm 0.002$ & $4.39 \pm 0.14$ & $1.67 \pm 0.06^{* * *}$ & $3.34 \pm 0.19$ & $0.54 \pm 0.07^{* * *}$ \\
\hline $\mathrm{PBI}$ & - & $3.21 \pm 0.06$ & $1.48 \pm 0.18^{* * *}$ & $2.82 \pm 0.11$ & $1.01 \pm 0.21^{* * *}$ \\
\hline PMA & $6.31 \pm 0.61$ & $44.89 \pm 1.18$ & $18.10 \pm 2.18^{* * *}$ & $32.19 \pm 1.54$ & $7.12 \pm 1.64^{* * *}$ \\
\hline $\begin{array}{c}\text { Amount of } \\
\text { crevicular fluids }\end{array}$ & $0.42 \pm 0.02$ & $2.42 \pm 0.14^{*}$ & $1.3 \pm 0.05^{* *}$ & $2.1 \pm 0.086$ & $0.9 \pm 0.05^{* *}$ \\
\hline
\end{tabular}

Note. Reliability of the difference between the indices of the main, the comparison and the control groups: ${ }^{*}-p<0.05^{* *}-p<0.01^{* * *}-p<0.001$

Table II. Dynamics of humoral immunity indices in patients of groups I and II before and in the nearest terms after treatment

\begin{tabular}{cccccc}
\hline & \multicolumn{5}{c}{ Immunological indices } \\
\hline $\begin{array}{c}\text { slgA } \\
\begin{array}{c}\text { Healthy } \\
\text { periodontium } \\
(\mathrm{n}=20)\end{array}\end{array}$ & $0.174 \pm 0.02$ & $\lg \mathbf{A}$ & $\lg \mathbf{~}$ & Ig $\mathbf{M}$ & CIC (units) \\
\hline
\end{tabular}

\begin{tabular}{cccccc}
\hline \multicolumn{5}{c}{} & I main group $(\mathbf{n}=\mathbf{4 8})$ \\
\hline Before treatment & $0.081 \pm 0.006$ & $2.01 \pm 0.31$ & $29.12 . \pm 1.59$ & $3.82 \pm 0.16$ & $141.1 \pm 17.1$ \\
\hline & $0.134 \pm 0.03$ & $1.76 \pm 0.35$ & $17.32 \pm 0.94$ & $2.21 \pm 0.18$ & $54.81 \pm 4.27$ \\
On the $7^{\text {th }}$ day after & $\mathrm{P} 1<0.01$ & $\mathrm{P} 1<0.01$ & $\mathrm{P} 1<0.01$ & $\mathrm{P} 1<0.01$ & $\mathrm{P} 1<0.001$ \\
stage II & $\mathrm{P} 2<0.05$ & $\mathrm{P} 2<0.05$ & $\mathrm{P} 3<0.01$ & $\mathrm{P} 3<0.05$ & $\mathrm{P} 3<0.05$
\end{tabular}

\begin{tabular}{cccccc}
\hline \multicolumn{5}{c}{ II comparison group $(\mathbf{n}=\mathbf{3 9})$} \\
\hline Before treatment & $0.097 \pm 0.007$ & $1.89 \pm 0.26$ & $23.8 \pm 1.28$ & $2.26 \pm 0.31$ & $102.04 \pm 12.36$ \\
\hline On the $7^{\text {th }}$ day after & $0.157 \pm 0.03$ & $1.57 \pm 0.21$ & $14.21 \pm 0.77$ & $1.84 \pm 0.25$ & $41.11 \pm 2.61$ \\
stage II & $\mathrm{P} 3<0.05$ & $\mathrm{P} 3<0.01$ & $\mathrm{P} 3<0.01$ & $\mathrm{P} 3<0.05$ & $\mathrm{P} 3<0.01$ \\
\hline
\end{tabular}

Note. P1- reliability of difference from the control group (healthy); P2- reliability of difference between the main and the comparison groups; $P 3$ - reliability of difference within the group between the indices before and after treatment. 
before and in the short term after the treatment are presented in table 2 .

\section{DISCUSSION}

In general, our study results are consistent with the data of other authors who studied manifestations of herpes virus infection in the oral cavity (Volosovets T.M., 2013, Petrushanko T.O, Skrypnikov P.M, Litovchenko I.Yu. et al., 2014) in the periodontal tissues pathology $[5,12]$. The efficacy of the "Dzherelo-I" phytocomplex has been proven by numerous studies performed at the Luhansk Regional Center for AIDS Prevention and Control (Chkhetiani R.D. 2003, 2004), Institute of Neurosurgery and Institute of Pediatrics, Obstetrics and Gynecology, NAMS of Ukraine, (Lisyanyi M.I., Pylypchuk V.S., Belska L.M. et al. 2018). It was designed as an adjunct to prevent the onset of herpesvirus pathology manifestations in the oral cavity of patients at treatment of moderate severity CGP. The data obtained during our studies are consistent with the results of the above authors [13].

\section{CONCLUSION}

The study on the dynamics of clinical indices and some humoral immunity indices confirmed that patients of group 1 (main) had positive shifts in the concentration of $\operatorname{sg} \mathrm{A}$ in the oral fluid and $\operatorname{Ig} A, \operatorname{IgG}, \operatorname{IgG}$ in the peripheral blood on the 7 th day after the second stage of closed curettage. In terms of their values, there was no statistically significant difference with similar patients in the comparison group. When comparing the number of complications and the recovery terms in patients of group I to the similar indices of group III patients, it was found that in group I complications in the form of manifestations in the oral mucosa were observed in $8.33 \%$ of persons with moderate and severe HVI course, which had a statistically significant difference $(p<0.001)$ from the percentage of patients with acute complications in group III (35.71\%).

Thus, the results obtained by us indicate that the "Dzherelo-I" phytocomplex, which contains a standardized number of phyto-drugs, has a pronounced antiviral, anti-inflammatory effect, significantly enhances the reparative function of the oral mucosa. In the comprehensive treatment of moderate severityCGP, it can be used as an immunomodulatory agent for prevention of herpes virus infection manifestations in the oral cavity of patients with interventions in the oral mucosa and periodontal tissues.

\section{REFERENCES}

1. Savychuk NO. Kolonizatsiyna rezystentnist' porozhnini rota [Colonization resistance of the oral cavity]. Ukrayins'kiy medychnyy chasopys [Ukrainian Medical Journal]. 2012; 4: 57-63 [inUkrainian]

2. Mills MP. Immunologikal and Inflammatory Aspekts of Periodontal Disease. Dentalcare. 2013; 1: 1-18.

3. Mohangi GU, Singh-Rambirich S, Volchansky A. Periodontal disease: Mekhanisms of infection and inflammation and possible impact on miscellaneous systemic diseases and conditions. SADJ. 2013;68:464-467.
4. Makarevych V.A. Patohenetychne obhruntuvannya korektsiyi porushennya imunnoyi reaktivnosti pry retsidyvniy herpetychniy infektsiyi rotovoyi porozhnyny [Pathogenetic justification for the correction of immune reactivity disorders in recurrent herpes infection of the oral cavity] [dysertatsiya]: 14.03.04. Rubizhne, 2016. 23 s. [in Ukrainian]

5. Volosovets TM. Zapalni zakhvoryuvannya tkanyn parodonta, asotsiyovani z persystuyuchoyu herpesvirusnoyu infektsiyeyu ta shlyakhy optimizatsiyi yikh profilaktyky, patohenetychnoyi terapiyi ta reabilitatsiyi [Inflammatory diseases of periodontal tissues associated with persistent herpes virus infection and ways to optimize their prevention, pathogenetic therapy and rehabilitation] [dysertatsiya] 14.01.22. Kyiv, 2013. 310 s. [in Ukrainian]

6. Bao L, Cowan MJ, Dunham K. Adoptive immunotherapy with CMVspecific cytotoxic T lymphocytes for stem cell transplant patients with refractory CMV infections J. Immunother. 2012; 35(3): 293-298. doi: 10.1097/ CJl.0b013e 31824300a2.

7. Doubrovina EB, Oflaz-Sozmen SE. Adoptive immunotherapy with unselected or EBV-specific T cells for biopsy-proven EBV + lymphomas after allogeneic hematopoietic cell transplantation. Blood. 2012; 119(11): 2644-2656.

8. Nigro G, Parruti AG. Immunoglobulin therapy of fetal cytomegalovirus infection occurring in the first half of pregnancy - a case-control study of the outcome in children. J. Infect. Dis. 2012; 205(2): 215-227.

9. Kravchenko AV. Obhruntuvannya dotsilnosti provedennya metodyky zakrytoho kyuretazhu u patsiyentiv iz heneralizovanym parodontytom II stupeniv vazhkosti, asotsiyovanoho iz persistuyuchoyu herpesvirusnoyu infektsiyeyu [Substantiation of the feasibility of conducting a closed curettage technique in patients with generalized periodontitis of II severity associated with persistent herpes virus infection]. Eksperymentalna i klinichna medytsyna [Experimental and clinical medicine]. 2019; 2 (83): 86-92. [In Ukrainian]

10. Hrih NI, Sidelnikov PV. Predyktory ryzyky uskladnen parodontalnoyi khirurhiyi [Predictors of risk of complications of periodontal surgery]. Novyny stomatolohiyi [Dentistry news]. 2013; 4: 26-30. [In Ukrainian]

11. Borysenko AV, Antonenko MYu, Sidelnikova LF. Praktychna parodontolohiya: dovidnyk likarya stomatoloha [Practical periodontics: a dentist's guide].Kyiv: Health of Ukraine. 2011. - 469 p. [In Ukrainian]

12. Petrushanko TO, Skripnikov PM, Lytovchenko IYu, Kolomiyets SV. Taktyka mistsevoho likuvannya khvorykh na khronichnyi heneralizovanyi parodontyt I-II stupeniv tyazhkosti [Tactics of local treatment of patients with chronic generalized periodontitis of I-II degrees of severity]. Visnyk problem biolohiyi i medytsyny [Bulletin of problems of biology and medicine]. 2014; 4 (116): 351-353. [In Ukrainian]

13. Lisyanyy NI, Pylypchuk VS, Byelska LM, et al. Immunomodulyuyuchyy vplyv preparatu"Dzherelo-I"na mikrobiotsenos i imunnu systemu [The immunological effect of the drug "Dzherelo-l" on microbiocenosis and the immune system]. Imunolohiya ta alerholohiya : nauka i praktyka [Immunology and Allergology: Science and Practice]. 2018; 1: 17-21. [In Ukrainian]

The work is a fragment of the research project at the Institute of Dentistry of the Shupyk National Medical Academy of Postgraduate Education "Clinical and laboratory substantiation of modern medical technologies application in the comprehensive treatment and rehabilitation of major dental diseases", state registration No. 0117 U006451. 
ORCID and contributionship:

Tetiana M. Volosovets: 0000-0001-9950-3748 B,C,D,F

Anna V. Kravchenko. 0000-0002-6581-3702 ${ }^{A, E, F}$

\section{Conflict of interest:}

The Authors declare no Conflict of interest:

\section{CORRESPONDING AUTHOR}

\section{Anna V. Kravchenko}

Dentistry Department at Shupyk National Medical Academy of Postgraduate Education, Kyiv, Ukraine.

tel: +380632437717

e-mail:annakravchenko7717@gmail.com

Received: 17.01 .2020

Accepted: 05.03 .2020

A - Work concept and design, B - Data collection and analysis, C - Responsibility for statistical analysis,

D-Writing the article, $\mathbf{E}$-Critical review, $\mathbf{F}$ - Final approval of the article 